\author{
Witold Brostow and Tea Datashvili
}

\title{
CHEMICAL MODIFICATION AND CHARACTERIZATION OF BOEHMITE PARTICLES
}

\author{
Laboratory of Advanced Polymers \& Optimized Materials (LAPOM), Department of Materials \\ Science and Engineering, University of North Texas, Denton, TX 76203 - 5310, USA; \\ http://www.unt.edu/LAPOM/; brostow@unt.edu,tcd0033@unt.edu
}

Received: January 10, 2008

\begin{abstract}
Polymerizable organic silane molecules 3-(trimethoxysilyl)propylmethacrylate (3MPS) and vinyltri(2-methoxyethoxy)silane (VTMES) have been introduced onto surfaces of high purity Boehmite (a commercial alumina) via hydroxyl groups on the oxides in order to obtain organic-inorganic hybrid "macromonomers". Changes of surface characteristics have been determined using thermogravimetric analysis (TGA) and Fouriertransform infrared spectroscopy (FTIR). The influence of the type of silane used and modification conditions have been determined. Preheating was applied to some Boehmite samples; it leads to lower concentrations of - $\mathrm{OH}$ groups on the powder surface and the adsorption yields lower than in samples without preheating. Modification leads to surface hydrophobicity and thus reduces significantly water adsorption; in TGA we see desorption of water below $423 \mathrm{~K}$ only in un-modified Boehmite.
\end{abstract}

Keywords: Boehmite, macromonomer, silica coupling agent, surface modification, powder filler.

\section{Introduction}

We see increasing use of fillers - including those containing ceramic oxides - in the development of polymer composites [1]. One thus obtains composites with better mechanical, thermal, electrical or other properties. This is particularly important for the ongoing process of gradual replacement of metallic components by polymer-based ones. The latter are weak mechanically [2] while ways of lowering wear are under development [3]. The properties of polymer-based composites are strongly influenced by the nature of the filler and also by adhesion between the filler particles and the polymer [4-16]. In fact, interfacial tensions are decisive for properties of multiphase materials [17]. The main problem here is the incompatibility of hydrophilic ceramic oxide fillers and hydrophobic polymer matrix which yields composites with poor properties. Thus, control and/or manipulation of the surface properties of the particles are of importance. We know that during the preparation process formation of covalent bonding between organic polymers and inorganic components contributes to enhancement of the compatibility in the composites. This can be achieved through the grafting of a polymerizable group onto the oxide surfaces via hydroxyl groups followed by its copolymerization with organic monomers [18-23]. Among others, silane coupling agents have been used to improve dispersion, adhesion and compatibility in such materials [24-28].

The purpose of the present work is modification and characterization of Boehmite, that is aluminum oxyhydroxide $(\mathrm{AlOOH})$ powder through adsorption of polymerizable organic silane molecules 3-(trimethoxysilyl)propylmethacrylate (3MPS) and vinyltri (2-methoxyethoxy)silane (VTMES) onto surfaces of ceramic oxide powders via hydroxyl groups on the oxides. In order to obtain organic-inorganic hybrid "macromonomers", effects of modification conditions have to be carefully determined to optimize the process.

Additional experiments were conducted on SCA modified Boehmite powders. These hybrid macromonomers were blended with low density polyethylene (LDPE). Investigation of powder loading and powder morphology effects on thermal, mechanical and tribological properties of the resulting materials is reported in another paper [29].

The present paper is one of a series dealing with polymer + ceramic oxide powder composites. There are other papers addressing the free radical copolymerization of the modified $\mathrm{SiO}_{2}$ oxides with methylacrylic monomers and the characterization of resulting organic-inorganic hybrids [12, 29, 30].

\section{Experimental}

\subsection{Materials}

Silane coupling agents (SCA), namely VTMES - SCA 972 and 3MPS - SCA 989 and high purity Boehmite (under the HiQ alumina trade name) were received as a gift from Struktol Company of America and Engelhard Co., respectively. Toluene was from Sigma Chemicals Co. All reagents were of analytical grade and were used as received. 


\subsection{Characterization of Boehmite sample}

Boehmite is a low cost material used in many areas; it is an important precursor because the heat treatment of Boehmite produces a series of transition aluminas from $\gamma-\mathrm{Al}_{2} \mathrm{O}_{3}$ and $\eta-\mathrm{Al}_{2} \mathrm{O}_{3}$ to $\delta-\mathrm{Al}_{2} \mathrm{O}_{3}$ and $\theta-\mathrm{Al}_{2} \mathrm{O}_{3}$, which exhibit high surface areas $\left(200-500 \mathrm{~m}^{2} / \mathrm{g}\right)$ and thermal stability up to $1273 \mathrm{~K}$.

Boehmite was thought to exist under two distinct forms, well-crystallized Boehmite and pseudoboehmite (also called gelatinous Boehmite) [31], with significantly different morphologies, porosity and surface areas. However, more recent studies [32, 33] have clearly demonstrated that pseudoboehmite is simply micro- or rather nano-crystallized Boehmite; the difference observed between the two forms comes from a difference in crystallite sizes.

Table 1 lists the chemical composition and physical properties of the Boehmite commercial ceramic powders.

The chemical composition and physical properties of commercial ceramic powders

\begin{tabular}{|lr|lr|}
\hline \multicolumn{2}{|c|}{ Chemical composition } & \multicolumn{2}{|c|}{ Physical properties } \\
\hline $\mathrm{Al}_{2} \mathrm{O}_{3}, \mathrm{wt} \%$ & 72 & Pore volume, $\mathrm{cm}^{3} / \mathrm{g}$ & $0.4-0.5$ \\
$\mathrm{Carbon}, \mathrm{wt} \%$ & $<0.3$ & Surface area, $\mathrm{m}^{2} / \mathrm{g}$ after $3 \mathrm{~h} 823 \mathrm{~K}$ & 270 \\
$\mathrm{SiO}_{2}, \mathrm{ppm}$ & $<150$ & Acid dispersibility, wt \% & 85 \\
$\mathrm{Fe}_{2} \mathrm{O}_{3}, \mathrm{ppm}$ & $<150$ & Loose bulk density, g/l & $670-750$ \\
$\mathrm{Na}_{2} \mathrm{O}, \mathrm{ppm}$ & $<20$ & Particle size $(\mathrm{d} 50), \mu \mathrm{m}$ & 55 \\
& & Crystallite size, $\mathrm{nm}$ & 4.3 \\
\hline
\end{tabular}

From Table 1 we see very small sizes of the crystallites. Generally, the structural elements in Boehmite crystals consist of double chains of $\mathrm{AlO}_{6}$ octahedra resulting in double molecules [34]:<smiles>C[AlH]1OCC[AlH]O1</smiles>

These chains are parallel, forming layers with the $\mathrm{OH}$ groups outside. The double chains are linked by hydrogen bonds between hydroxyl ions. Boehmite crystals exhibit perfect cleavage perpendicular to the general direction of the hydrogen bonding [35].

\subsection{Grafting of SCA onto ceramic particles}

Introduction of reactive groups onto the commercially obtained and preheated at $3 \mathrm{~h} 823 \mathrm{~K}$ ceramic surfaces was achieved by a reaction of SCA with the hydroxyl groups of alumina. Two different types of SCA were used and the temperature dependence of the process was characterized.

A typical example can be described as follows. Reaction mixture contained $25 \mathrm{ml} \mathrm{SCA}, 200 \mathrm{ml}$ of toluene and $20 \mathrm{~g}$ of powder. After dispersing the powder in solvent SCA was added and the resulting mixture refluxed at the boiling temperature of the solution for $24 \mathrm{~h}$. The process was also conducted with $24 \mathrm{~h}$ mixing at room temperature.
Afterwards the powder was centrifuged and washed with fresh toluene for $24 \mathrm{~h}$ to remove the excess SCA absorbed on the surfaces. Final products were dried at $363 \mathrm{~K}$ under vacuum for $24 \mathrm{~h}$.

\subsection{Characterization techniques}

All the samples were analyzed by TGA in nitrogen atmosphere at the heating rate of $10 \mathrm{~K} / \mathrm{min}$. The technique has been described by Menard and his colleagues [36, 37].

Isothermal thermogravimetry (TG) was used to determine a temperature profile. A Perkin Elmer TGA-7 instrument was used. Several milligrams of each dried sample were placed on a balance located in the furnace which was heated over the temperature range from 323 to $973 \mathrm{~K}$.

The FTIR spectra were recorded on a Nexus 470 FTIR ESP Series spectrometer at the resolution of $4 \mathrm{~cm}^{-1}$ wave number, in the midinfrared range from 4000 to $250 \mathrm{~cm}^{-1}$. To enhance the signal to noise ratio, each of the reference and sample spectra presented constitutes an average of 40 scans recorded.

For infrared spectroscopy measurements, CsI pellets containing $1 \mathrm{wt} \%$ of material were used and the background noise was corrected with pure CsI data.

\section{Results and Discussion}

\subsection{Characteristics of the surface modified Boehmite}

The basic principles of the surface modification of ceramic powder are presented schematically in Figure 1: 


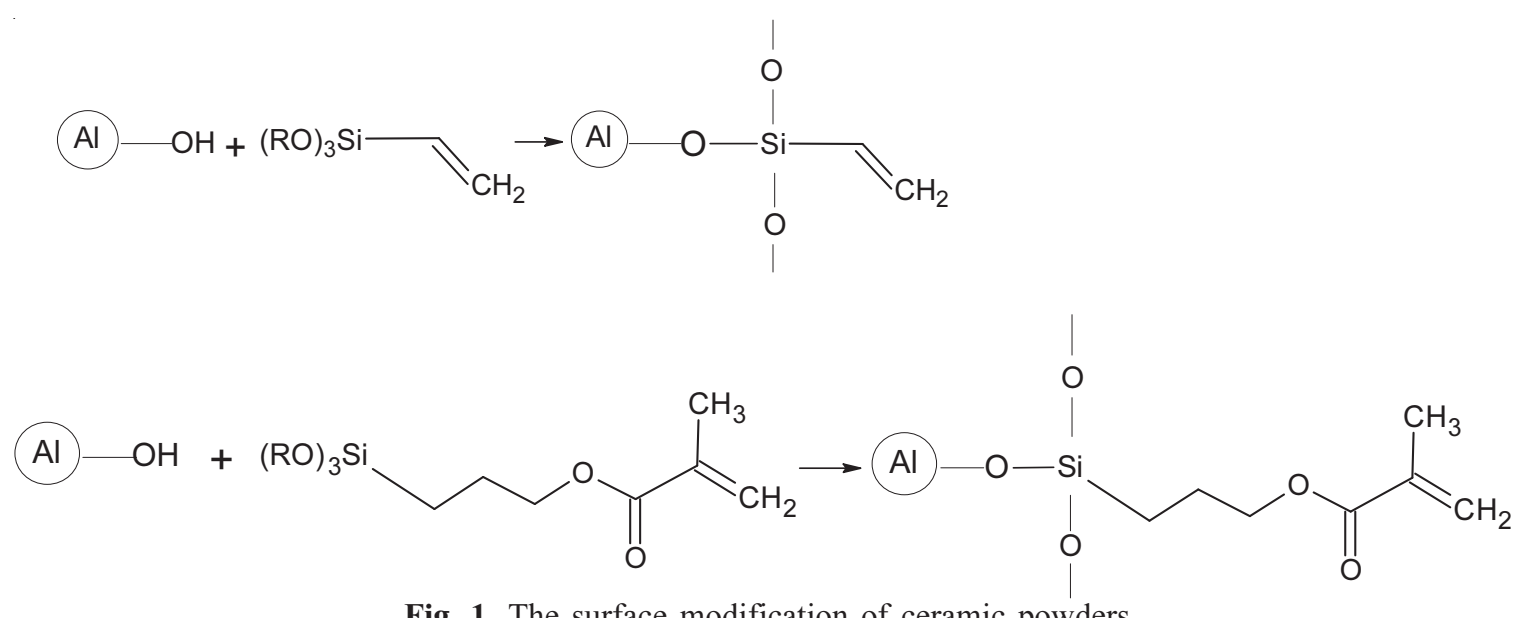

Fig. 1. The surface modification of ceramic powders

Formation of new groups on powder surfaces was investigated by Fourier-transform infrared (FTIR) spectroscopy which is sensitive to both inter- and intramolecular interactions. Fig. 2 shows the FTIR spectra of Boehmite powder before and after modification with two polymerizable organic silane molecules, 3MPS and VTMES, onto surfaces of ceramic oxide powders via hydroxyl groups on the oxides.

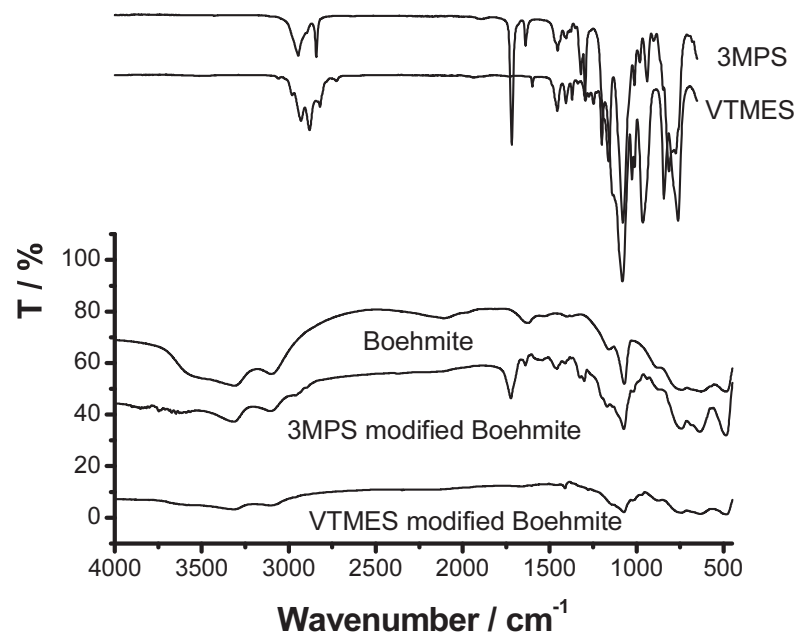

Fig. 2. FTIR of Boehmite powder before and after modification

We see that the samples exhibit stretching vibrations of $-\mathrm{OH}$ groups in the $3000-3600 \mathrm{~cm}^{-1}$ range. The vibrations appear for unmodified Boehmite powder as strong peaks. These peaks are characteristic for the $-\mathrm{OH}$ fragments of physisorbed water. A small fraction of these $-\mathrm{OH}$ groups also appears in modified samples. They are evidence of the same physisorbed water. Furthermore, we can see a different picture in the case of preheated Boehmite powder (Fig. 4); namely, these samples do not exhibit stretching peaks in the $3000-3600 \mathrm{~cm}^{-1}$ range due to the desorption of physisorbed water after heating above $773 \mathrm{~K}$. The TGA diagram in Fig. 3 supports these results, as indicated by the main weight loss between 373 and $773 \mathrm{~K}$.

The reaction that takes place can be simply represented by

$3 \mathrm{AlOOH} \rightarrow \mathrm{Al}_{2} \mathrm{O}_{3}+\mathrm{AlOOH}+\mathrm{H}_{2} \mathrm{O}$

The dehydration of the Boehmite appears to occur in three main steps. The first gives a sharp symmetrical endotherm and ends at $423 \mathrm{~K}$. It accounts for 10-13 wt \% of the mass loss. The second step gives a broad unsymmetrical endotherm and ends before $773 \mathrm{~K}$. It represents the major part of the mass loss, about 15-17 wt \%. The last step does not correspond to a specific thermal event but appears as a continuous mass loss. It only corresponds to about 2-3 wt $\%$ of the mass loss.

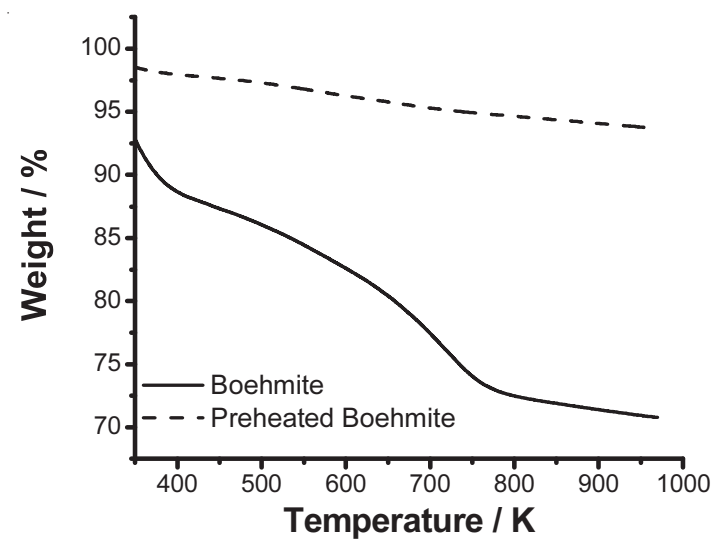

Fig. 3. TGA scans of Boehmite powder before and after heating

The first step has been attributed to the desorption of physically adsorbed water, the second step to the conversion of Boehmite into $\alpha$-alumina, and the last step to elimination of residual hydroxyls. Several authors [34, $35,38,39$ ] explain the asymmetrical profile of the second peak by removal of chemisorbed water before the convertion into alumina. 

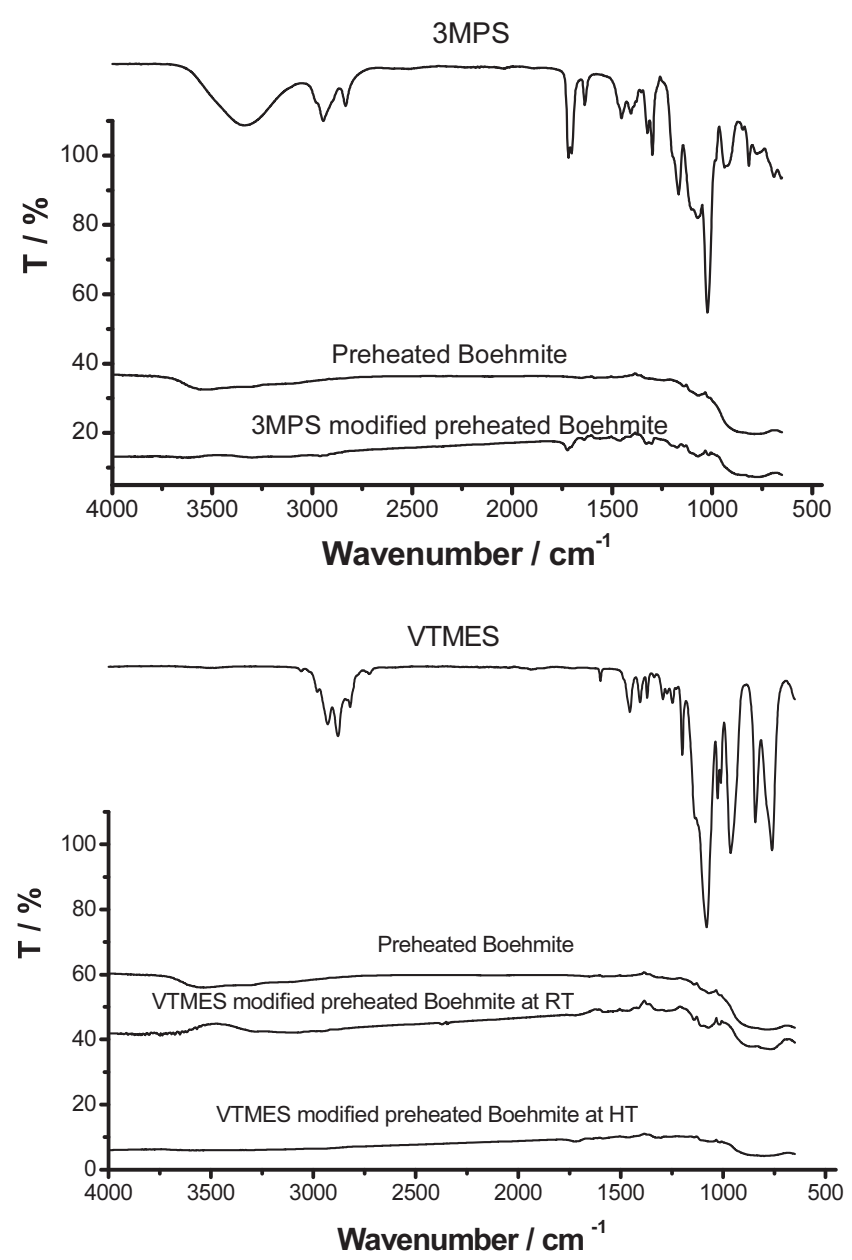

Fig. 4. FTIR of preheated Boehmite powder before and after modification

For modified Boehmite samples small trace peaks in the region $2800-3000 \mathrm{~cm}^{-1}$ are associated with the methylene $\left(-\mathrm{CH}_{2}-\right)$ and dimethylene $\left(-\mathrm{CH}_{2}-\mathrm{CH}_{2}-\right)$ stretching which comes from polymerizable organic molecule contamination. We see the same stretching peaks in the 2800-3000 $\mathrm{cm}^{-1}$ range for polymerizable organic silane molecules.

Compared with unmodified powder, formation of peaks is observed in the $800-1700 \mathrm{~cm}^{-1}$ region. These signals are characteristic for the silane coupling agents.

The characteristic peaks for the modified powders have the absorption bands at the $1500-1750 \mathrm{~cm}^{-1}$ and $1000-1500 \mathrm{~cm}^{-1}$ range which correspond to unsaturated bands of the SCA. The strong signal at $1733 \mathrm{~cm}^{-1}$ is characteristic of the carbonyl $(\mathrm{C}=\mathrm{O})$ stretching of the SCA 989 (Fig. 2); the peaks decrease in size for SCA 989 grafted onto the surfaces of preheated Boehmite powders. This can be explained by decreasing amounts of $-\mathrm{OH}$ groups on the powder surfaces after heating at $823 \mathrm{~K}$ for $3 \mathrm{~h}$ immediately before modification (Fig. 4). As expected, the mass loss for preheated Boehmite below $823 \mathrm{~K}$ is only
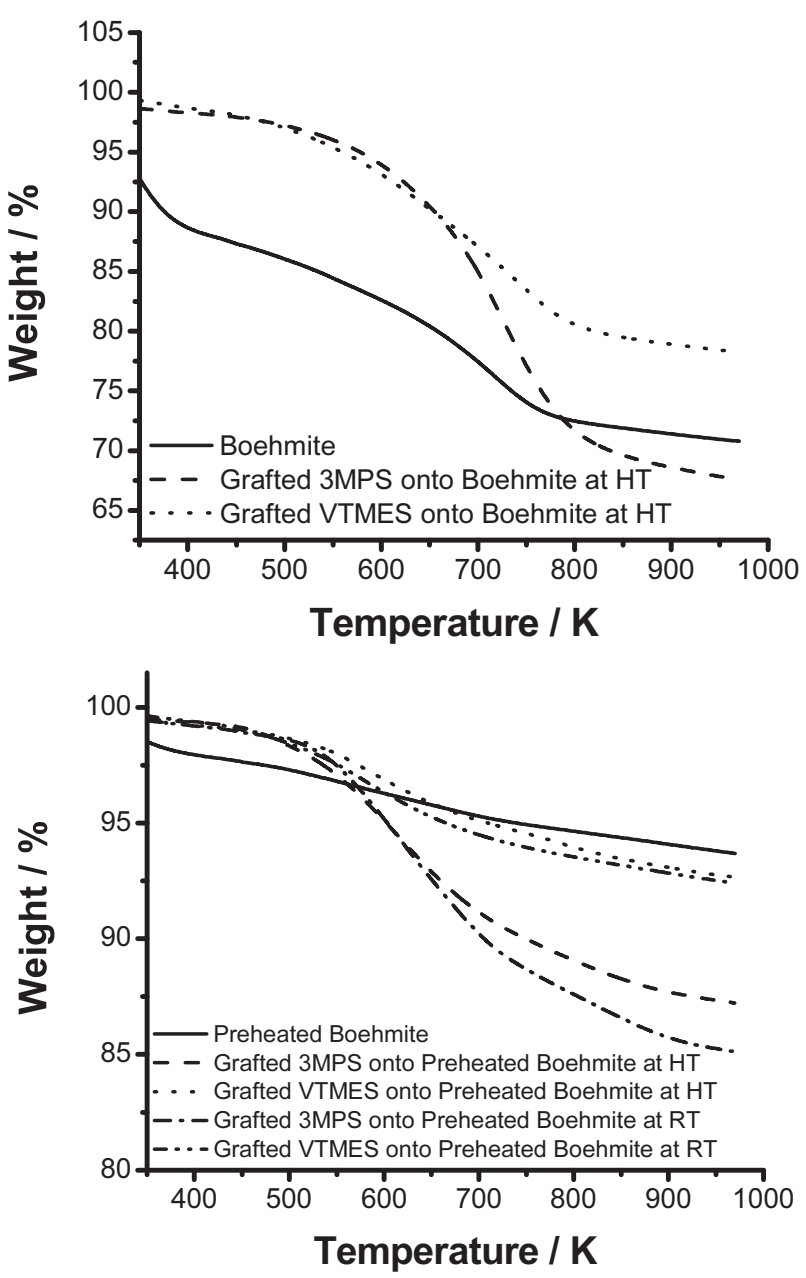

Fig 5. TGA scans of Boehmite and preheated Boehmite powders before and after modification

5.0-7.0 wt \% while for the Boehmite powder a significant mass loss 25.0-27.0\% occurs below $823 \mathrm{~K}$ (Fig. 3).

As noted above, to evaluate organic group reactivity in the modification process of Boehmite surfaces we have used SCA 972 and SCA 989 with vinyl and methacryl groups respectively. The experiments show clearly more chemical activity of the methacryl groups in SCA 989. Formation of larger amounts of organic-inorganic hybrid macromonomers takes place. At the same time SCA 972 provides lower activity and exhibits nearly the same grafting efficiency for both Boehmite powders. On the other hand, both SCAs provide higher yields of adsorption onto the Boehmite particles as compared to preheated samples.

As observed by other authors [26, 40] the main peak at $1699 \mathrm{~cm}^{-1}$ indicates that SCA 989 monomers are successfully adsorbed onto the Boehmite and preheated Boehmite powder surfaces (Figs. 2 and 4) through covalent bonding. The second system shows weaker interactions between functional groups of SCA 972 and 
hydroxyl groups of the preheated powder and even weaker ones for unheated powder.

A significant difference in thermal behavior between the unmodified and modified Boehmite samples (Fig. 5) also indicates the role of the modification efficiency.

At the same time, TGA data reveal hydrophobic characteristics of the modified powder surfaces; the mass loss is significant only above $423 \mathrm{~K}$ while for unmodified powders such loss occurs below $423 \mathrm{~K}$ due to physisorbed water desorption. The thermograms of all the modified samples show two regions of characteristic weight loss at $423-623 \mathrm{~K}$ and $623-823 \mathrm{~K}$. This can be explained by a decomposition of the organic constituent of the grafted SCA.

From TGA curves we also see that the modification process remains the same when reaction temperature ranges from room to boiling. The use of high temperature treatment did not cause marked improvement in percentage modification and adsorption efficiency - as we see in Fig. 5.

Apparently introduction of new groups onto microsize Boehmite surfaces takes place. A large excess of the SCA or an increase of the process temperature does not significantly affect the products since the amounts of group adsorbed onto the surfaces appears to be limited. Apparently, growing adsorbed chains of SCA on the powder surfaces have a blocking effect on the diffusion of monomers to the surfaces of Boehmite particles.

As already mentioned, mechanical properties of low density polyethylene (LDPE) reinforced with Boehmite grafted as described above are reported elsewhere [29]. Finally, we note a large variety of current and potential uses of Boehmite. To give just one more example, metal catalysts of hydrogenation reactions in oil refinery industry can be deposited on porous Boehmite [41].

\section{Acknowledgments}

A partial financial support was provided by the Robert A. Welch Foundation, Houston (Grant B-1203). T. D. acknowledges also support of the Georgian Research Development Foundation (GRDF), Tbilisi.

\section{References}

[1] Rabello M.: Aditivacao de Polimeros. Artliber, Sao Paulo 2000.

[2] Brostow W. and Simoes R.: J. Mater. Ed., 2005, 27, 19.

[3] Brostow W., Deborde J.L., Jaklewicz M. and Olszynski P.:

J. Mater. Ed., 2003, 24, 119.

[4] Mark H. F.: J Mater. Ed., 1990, 12, 65.

[5] Brostow W. (ed.): Failure of Plastics. Hanser, MunichVienna-New York 1992.

[6] D'Almeida L.M. and de Carvalho L.H.: J. Mater. Sci., 1998, 33, 2215.

[7] Schwartz C.J. and Bahadur S.: Wear, 2000, 237, 261.

[8] Rong M., Zhang M., Zheng Y., Zeng H., Walter R. and Friedrich K.: Polymer, 2001, 42, 167.
[9] Rong M., Zhang M., Zheng Y., Zeng H. and Friedrich K.: Polymer, 2001, 42, 3301.

[10] Brostow W., Kaselman M., Mironi-Harpaz I., Narkis M. and Peirce R.: Polymer, 2005, 46, 5058.

[11] Brostow W., Gorman B. and Olea-Mejia O.: Mater. Lett., 2007, 61, 1333.

[12] Zhao M. and Liu P.: Mater. Res. Innovat., 2007, 11, 32.

[13] Perez L., Giraldo L., Brostow W. and Lopez B.: e-Polymers, 2007, 029.

[14] Bakar M. and Skrzypek K.: Mater. Sci.-Medziagotyra, 2007, 13,39 .

[15] Bilyeu B., Brostow W., Chudej L., Estevez M., Hagg Lobland H., Rodriguez J. and Vargas S.: Mater. Res. Innovat, 2007, 11, 181.

[16] Giraldo L., Brostow W., Deveux E., Lopez B. and Perez L.: J. Nanosci. Nanotech., 2008, 8, in press.

[17] Kopczynska A. and Ehrenstein G.: J. Mater. Ed., 2007, 29, 325.

[18] Oosterling M., Sein A. and Schouten A.: Polymer, 1992, 33, 4394.

[19] Espiard P. and Guyot A.: Polymer, 1995, 23, 4391.

[20] Liu Q., Wijn J., Groot K. and Blitterswijk C.: Biomaterials, 1998, 19, 1067.

[21] Tsubokawa N., Shirai Y. and Hashimoto K.: Colloid \& Polymer Sci., 1995, 273, 1049.

[22] Tsubokawa N., Kogure A. and Sone Y.: J. Polymer Sci. Chem., 1990, 28, 1923.

[23] Webster O.: Science, 1991, 251, 887.

[24] Plueddemann E.: Silane coupling agents. Plenum, New York 1982.

[25] Barboiu M., Luca C., Guizard C., Hovnanian N., Cot L. and Popescu G.: J. Membr. Sci., 1997, 129, 197.

[26] Haan D., Bogaert V., Ponjee J. and Ven V.: J. Colloid \& Interface Sci., 1986, 110, 591.

[27] Tsubokawa N., Maruyama K., Sone Y. and Shimomura M.: Polymer, 1989, 21, 475.

[28] Rong M., Ji Q., Zhang M. and Friedrich K.: Eur. Polymer J., 2002, 38, 1573.

[29] Brostow W., Datashvili T., Huang B. and Too J.: Polymer Compos., 2007, 28, in print.

[30] Brostow W., Datashvili T. and Hackenberg K.: e-Polymers, 2008 , to be published.

[31] Bagwell R. and Messing G.: Key Eng. Mater., 1996, 115, 45.

[32] Bokhimi X., Toledo-Antonio J., Guzman-Castillo M. and Hernandez-Beltran F.: J. Solid State Chem., 2001, 159, 32.

[33] Gobichon A., Rebours B. and Euzen P.: Mater. Sci. Forum, 2001, 378-381, 523.

[34] Lippens B. and de Boer J.: Acta Crystallogr., 1964, 17.

[35] Alphonse P. and Courty M.: Thermochim. Acta, 2005, 425, 75.

[36] Bilyeu B., Brostow W. and Menard K.: J Mater. Ed., 2000, 22, 107.

[37] Menard K. Ch. 8 [in:] Brostow W. (ed.), Performance of Plastics. Hanser, Munich-Cincinnati 2000.

[38] Tsukada T., Segawa H., Yasumori A. and Oakada K.: J. Mater. Chem., 1999, 9, 549. 
[39] Nguefack M., Popa A., Rossignol S. and Kappenstein C.: Phys. Chem. \& Chem. Phys., 2003, 19, 4279.

[40] Abboud M., Turner M., Duguet E. and Fontanille M.: J. Mater. Chem., 1997, 7, 1527.

[41] Yem H., Kim K., Kim J., Choa Y.-H. and Kim H.: J. Ind. Eng. Chem., 2007, 13, 644.

\section{ХІМІЧНА МОДИФІКАЦІЯ І ХАРАКТЕРИСТИКА БЕМІТОВИХЧАСТИН}

Анотація. Показано, щцо полімеризаційноздатні органічні силанові молекули 3-(триметоксисиліл) пропілметакрилату та вінілтри(2-метоксиетокси)силану для одержання органічно-неорганічного гібриду “макромо- номерів" можуть бути введені на поверхню бемітів високої чистоти (промисловий глинозем) за допомогою гідроксильних груп на оксиди. Зміни у поверхневих характеристиках визначені термогравіметричним аналізом (ТГА) та інфрачервоною спектроскопією з перетворенням Фурьє. Визначено вплив типу силану та умови процесу модифікування. Встановлено, щуо у попередньо нагрітих зразках спостерігається зменшення концентрації-ОН груп на поверхні і зменшення адсорбиійного виходу порівняно із зразками без нагрівання. Модифікачія приводить до гідрофобності поверхні, внаслідок чого значно змениується адсорбиія води; за результатами ТГА десорбиія води нижче 423 Кмає місче тільки в немодифікованих бемітах.

Ключові слова: беміт, макромономер, кремнеземний агент, модифікація поверхні, порошковий наповнювач. 